\title{
A Survey of \\ Dynamic Games in Economics
}


This page is intentionally left blank 
A Survey of Dynamic Games in Economics

\section{Ngo Van Long}

McGill University, Canada 
Published by

World Scientific Publishing Co. Pte. Ltd.

5 Toh Tuck Link, Singapore 596224

USA office: 27 Warren Street, Suite 401-402, Hackensack, NJ 07601

UK office: 57 Shelton Street, Covent Garden, London WC2H 9HE

\title{
British Library Cataloguing-in-Publication Data
}

A catalogue record for this book is available from the British Library.

\begin{abstract}
A SURVEY OF DYNAMIC GAMES IN ECONOMICS Surveys on Theories in Economics and Business Administration - Vol. 1

Copyright (C) 2010 by World Scientific Publishing Co. Pte. Ltd.

All rights reserved. This book, or parts thereof, may not be reproduced in any form or by any means, electronic or mechanical, including photocopying, recording or any information storage and retrieval system now known or to be invented, without written permission from the Publisher.
\end{abstract}

For photocopying of material in this volume, please pay a copying fee through the Copyright Clearance Center, Inc., 222 Rosewood Drive, Danvers, MA 01923, USA. In this case permission to photocopy is not required from the publisher.

ISBN-13 978-981-4293-03-7

ISBN-10 981-4293-03-2

Typeset by Stallion Press

Email: enquiries@stallionpress.com

Printed in Singapore. 
This book is dedicated to Kim-Chau, Bach, Chi, Eric, and Bambou. 
This page is intentionally left blank 


\section{CONTENTS}

Preface $\quad$ xi

Introduction xiii

1. Basic Concepts 1

1.1 What Are Dynamic Games? . . . . . . . . . . . . . . 1

1.2 Open-loop Nash Equilibirum and Markov-perfect Nash Equilibrium .................... 2

1.2.1 A simple transboundary pollution game in discrete time..................... 4

1.2.2 Choice among equilibrium concepts . . . . . . . 11

1.2.3 Another simple dynamic game: non-cooperative cake eating . . . . . . . . . . . . 12

1.2.4 An infinite horizon game of transboundary pollution in continuous time . . . . . . . . . 14

1.3 Stackelberg Equilibrium . . . . . . . . . . . . . . 26

1.3.1 Open-loop Stackelberg Equilibrium . . . . . . . . . 27

1.3.2 Feedback Stackelberg Equilibrium . . . . . . . . . 31

2. Dynamic Games in Environmental Economics 35

2.1 Models of Transboundary Pollution and Global Warming . . . . . . . . . . . . . . . . 35

2.2 Empirical Models of Transboundary Pollution Games . . . 37

2.3 Carbon Taxes under Bilateral Monopoly . . . . . . . . . 39

2.3.1 Nash equilibrium under costless extraction and non-decaying pollution . . . . . . . . . 40

2.3.2 Stagewise Stackelberg leadership by the seller under costless extraction and non-decaying pollution . . . 45

2.3.3 Bilateral monopoly under stock-dependent extraction cost and non-decaying pollution . . . . . 48

2.3.4 Models of carbon taxes with pollution decay . . . . 51

2.4 International Environmental Agreements . . . . . . . . . 51

2.4 .1 IEA membership game . . . . . . . . . . . . 52 
2.4 .2 Effects of delays . . . . . . . . . . . . . . 53

2.4.3 Games under the Kyoto Protocol . . . . . . . . 55

2.5 Taxation Issues . . . . . . . . . . . . . . . 56

2.5.1 Efficiency-inducing tax on emissions: monopoly or oligopoly as follower and government as leader . . . 56

2.5.2 Prices versus quantities . . . . . . . . . . . 61

2.5.3 Tax adjustment rule to achieve a long-run pollution target . . . . . . . . . . . . . 6 61

2.5.4 Non-point-source pollution taxes . . . . . . . . . 62

2.6 Environmental Games with Coupled Constraints . . . . . . 63

2.6.1 A static model of global pollution with and without a coupled constraint . . . . . . . . . . 63

2.6.2 Models of environmental games with coupled constraints . . . . . . . . . . . . . . 69

3. Dynamic Games in Natural Resources Economics 71

3.1 Renewable Resources . . . . . . . . . . . . . . . . . . . 71

3.1.1 The tragedy of the commons . . . . . . . . . 71

3.1.2 Can Nash equilibria in renewable-resource exploitation be Pareto efficient? . . . . . . . . . . 79

3.1.3 Some technical notes on feedback strategies in fishery problems . . . . . . . . . . . . 82

3.1.4 Differential game models of an oligopolistic fishery . 89

3.1.5 Entry deterrence . . . . . . . . . . . . . . 92

3.1 .6 Further results . . . . . . . . . . . . . . . . . 93

3.2 Non-Renewable Resources . . . . . . . . . . . . . . . . . 94

3.2.1 Dynamic games with a non-renewable resource: open-loop equilibrium . . . . . . . . . . . . . 94

3.2.2 Dynamic games with a non-renewable resource: feedback equilibrium . . . . . . . . . . . 98

3.2.3 Optimal tariff on exhaustible resources: dynamic games . . . . . . . . . . . . . . . . . . 99

3.2.4 Optimal taxation and principal-agent problems with extractive firms . . . . . . . . . . . . 101

3.2.5 Dynamic games with investment in $R \& D$ for a substitute for a non-renewable resource . . . . . . 102

3.2.6 Common property non-renewable resource and capital accumulation games . . . . . . . . . . . 103 
3.3 Related Topics: Recycling, Drug Resistance, and Pesticide Resistance . . . . . . . . . . . . . . . . . 104

4. Dynamic Games in Trade and Development Economics 107

4.1 International Oligopoly and Trade Policies . . . . . . . . . 107

4.2 Feedback Trade Policies under Bilateral Monopoly . . . . . 113

4.3 Time-inconsistency of Open-loop Trade Policies . . . . . . 115

4.4 Optimal Export Tax by a Resource-Exporting Country . . 118

4.5 Optimal Tariff by Resource-Importing Countries . . . . . . 120

4.5.1 Optimal tariff under rational expectations, when sellers are perfectly competitive . . . . . . . . 120

4.5.2 Optimal tariff when the seller is a monopolist . . . 127

4.6 Foreign Aid and Capital Flight from Poor Countries to Rich Countries . . . . . . . . . . . . . . . . . 128

4.6.1 Foreign aid as a dynamic game . . . . . . . . . 128

4.6.2 Capital flights as a result of rent-seeking by powerful groups . . . . . . . . . . . 130

5. Dynamic Games in Industrial Organization 137

5.1 Dynamic Oligopoly . . . . . . . . . . . . . . . 137

5.1 .1 The sticky price model . . . . . . . . . . . . 138

5.1.2 Investment in capacity by Cournot oligopolists . . . 141

5.1.3 Bertrand rivalry with costly price adjustments . . . 147

5.1.4 Bertrand rivalry with costly output adjustments . . . . . . . . . . . . . . 148

5.1.5 Going beyond the linear quadratic model . . . . . . 149

5.2 Extensions of Dynamic Oligopoly Games . . . . . . . . . 149

5.2.1 Dynamic oligopoly with far-sighted consumers . . . 150

5.2.2 Oligopolistic extraction of natural resources . . . . 154

5.3 R\&D Races and Technology Adoption . . . . . . . . . . 154

$5.3 .1 \quad$ R\&D races . . . . . . . . . . . . . . . . . 155

5.3 .2 Technology-adoption games. . . . . . . . . . 163

6. Dynamic Games in Public Economics 173

6.1 Contributions to a Stock of Public Good . . . . . . . . . . 173

6.1.1 Tangible public goods . . . . . . . . . . . . 173

6.1.2 Trust: an intangible stock of public good that promotes co-operative behavior . . . . . . . . . 178 
6.2 Contributions to a Discrete Public Good . . . . . . . . . . 184

6.2.1 The co-operative solution . . . . . . . . . . . 185

6.2 .2 Open-loop Nash equilibria . . . . . . . . . . . . 187

6.2.3 Markov-perfect Nash equilibria . . . . . . . . . . . 188

6.3 Corrective Taxation with Far-sighted Firms . . . . . . . . 191

6.4 Redistributive Taxation . . . . . . . . . . . . . . . 196

6.5 Altruism, Distributive Justice, and Intergenerational Equity 197

6.6 Fiscal Competition and Electoral Incentives . . . . . . . 202

6.6.1 Factor mobility and fiscal competition . . . . . . . 202

6.6.2 Electoral incentives, corruption, and local public

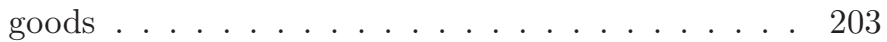

7. Dynamic Games in Macroeconomics 211

7.1 Macroeconomic Policies . . . . . . . . . . . . . . . . . 211

7.1.1 Dynamic games between a policymaker and the private sector . . . . . . . . . . . 211

7.1.2 Political economy of monetary and fiscal policies . . . . . . . . . . . . 218

7.1.3 Dynamic games of macroeconomic policies between two countries . . . . . . . . . . . . . . . 224

7.2 Wealth Distribution and Endogenous Property Rights . . . 229

7.3 Capitalists versus Workers . . . . . . . . . . 236

$\begin{array}{ll}\text { References } & 243\end{array}$

$\begin{array}{ll}\text { Index } & 273\end{array}$ 


\section{PREFACE}

This book originates from my years of teaching economic dynamics at McGill University and the Australian National University. I have found that most students would like to be exposed to a wide variety of dynamic game models, with applications to various fields of economics.

This book is intended to present a broad picture of dynamic games in economics. As a result, I deliberately avoid dealing with issues that would appear excessively technical for most graduate students and for economists with a general $\mathrm{PhD}$ training in economics. Those who prefer reading treatments of the subject at a higher level of formalism should consult graduate-level textbooks or treatises, such as Dockner et al. (2000), Differential Games in Economics and Management Science, or Başar and Olsder (1995), Dynamic Noncooperative Game Theory.

A decade has passed since the publication of Dockner et al. (2000). While the present work refers to quite a number of articles published between 2000 and 2010, it is not meant to be an update on that volume. The two volumes are complements, not substitutes. This work is also a complement to Jørgensen and Zaccour (2004), Differential Games in Marketing.

A good friend of mine, the late Jean-Jacques Laffont, told me a memorable story. In writing his books, Fundamentals of Public Economics, and The Economics of Information and Uncertainty, he faced an "adverse selection" problem: among many good papers and models that deal with the same subjects, which ones should he select for a detailed exposition? He decided to take the risk of appearing biased toward articles of which he was either an author or a co-author, one of the reasons being that he had a comparative advantage in explaining them. I have taken the same risk, for the same reasons. Naturally, in a survey, one must be selective: one cannot give equal treatments to equally good papers. Like a tour guide, I allocate more time (and space) to articles that I think the readers would find interesting and yet not too hard to grasp.

While the actual preparation of this book took about 18 months, it is not an exaggeration to say that its gestation period is more than 
three decades. During my journey, I have benefited from discussions with many friends and co-authors. They have reinforced my interest in economic modelling, dynamic optimization, and dynamic games. I would like to thank Francisco Alvarez-Cuadrado, Jean-Pierre Amigues, Venkatesh Bala, Sanjay Banerji, Joydeep Bhattacharya, Hassan Benchekroun, Richard A. Brecher, Edwin Burmeister, Jim Cassing, Carl Chiarella, Richard Cornes, Engelbert Dockner, Charles Figuières, Bruce Forster, Kenji Fujiwara, Gérard Gaudet, John M. Hartwick, Horst Herberg, Arye Hillman, Nguyen Manh Hung, Steffen Jørgensen, Larry Karp, Seiichi Katayama, Murray C. Kemp, Toru Kikuchi, Pierre Lasserre, Jean-Jacques Laffont, Didier Laussel, Daniel Léonard, Xiao Luo, Richard Manning, Stephanie McWhinnie, Michel Moreaux, Kazuo Nishimura, Koji Okuguchi, Hiroshi Ohta, John Pitchford, Horst Raff, Ray Rees, Ray Riezman, Koji Shimomura, Horst Siebert, HansWerner Sinn, Gerhard Sorger, Antoine Soubeyran, Raphaël Soubeyran, Frank Stähler, Hideo Suzuki, Haru Takahashi, Makoto Tawada, Mabel Tidball, Binh Tran-Nam, Stephen Turnovsky, Neil Vousden, and Kar-Yiu Wong.

Other colleagues and many of my students have provided valuable inputs, comments, and feedback. My thanks go in particular to Gustav Feichtinger, Philippe Michel, Rick van der Ploeg, Steve Salant, Henry Y. Wan, Jr., Cees Withagen, Georges Zaccour, Soham Baksi, Enrique Calfucura, Steven Chou, Engin Dalgic, Viet Do, Isabel Galiana, Octave Keutiben, Bodhi Sengupta, and Shengzu Wang.

I am particularly grateful to Murray C. Kemp, Kim-Chau Long and Kenji Fujikawa for reading the entire typescript, making corrections and offering suggestions for expositional and stylistic improvements. Needless to say, I am responsible for the remaining errors. 


\section{INTRODUCTION}

Dynamic games, introduced to economics by Roos (1925, 1927), and neglected until the early 1970s, have become a standard tool of economic analysis. Indeed, one of the emerging trends in the expanding relationship between game theory and economics is the application of dynamic/stochastic games in a variety of settings. Dynamic games include differential games (set in continuous time), difference games (set in discrete time), and timing games.

While early economic articles using dynamic games mostly appeared in highly technical journals or volumes, nowadays one easily comes across papers using dynamic games in mainstream general journals such as the American Economic Review, Journal of Political Economy, Economic Journal, Canadian Journal of Economics, European Economic Review, Oxford Economic Papers, Economica, Scandinavian Journal of Economics, Japanese Economic Review, and in field journals such as Journal of Public Economics, International Journal of Industrial Organization, Journal of International Economics, Journal of Public Economic Theory, Review of International Economics, Journal of Development Economics, Journal of Environmental Economics and Management, Resource and Energy Economics, Environmental Modelling and Assessment, and many others.

The purpose of this volume is to present a survey of the development of dynamic games in economics, with special emphasis on applications. An excellent survey was provided by Clemhout and Wan (1994). Since then, there have been many economic articles with further applications of differential games. This fact alone is sufficient to justify my enterprise. I must stress that this volume is not meant to be a comprehensive treatment of differential games. Readers interested in precise definitions and fine points are referred to books on dynamic games (e.g., Başar and Olders, 1995; Dockner et al. 2000). The latter also contains many applications in economics and management science. I will assume that the reader has some working knowledge of optimal control theory and dynamic programming, for which there are several good books (e.g., Léonard and Long, 1992; Kamien and Schwartz, 1991). 
Economists have used dynamic games to analyze a variety of problems in various fields. In this volume, I survey dynamic games in environmental economics (Chap. 2), natural resources economics (Chap. 3), international economics and development economics (Chap. 4), industrial organization (Chap. 5), public economics (Chap. 6), and macroeconomics (Chap. 7). Naturally, there are overlaps and omissions, for which I apologize.

My wish is that this book will stimulate the reader's interests in the use of dynamic games to analyze new problems or old problems from a new perspective. The next step would be to equip yourself with a pencil, a piece of paper, and a good textbook on differential game. Bon voyage! 